\title{
Pelatihan Geogebra sebagai media pembelajaran matematika pada guru-guru SMP di Kota Mataram tahun 2021
}

\author{
Amrullah $^{1^{*}}$, Nilza Humaira Salsabila ${ }^{2}$, Junaidi ${ }^{3}$, Hapipi $^{4}$, Sudi \\ Prayitno $^{5}$
}

1,2,3,4,5 Pendidikan Matematika, FKIP, Universitas Mataram, Mataram

amrullah@unram.ac.id

\begin{abstract}
In the 2019 survey, $82.2 \%$ of teachers never participated in media training, especially learning media based on geogebra technology. Meanwhile, $92.8 \%$ of teachers stated that mathematics requires learning media. The low quality of education in NTB requires special attention from both the government and the private sector, so it is important to conduct technology-based learning media training in order to improve the quality of education, especially improving the quality of teachers. The training was carried out using offline and online methods for two days, 19 and 20 August 2021 at SMPN 16 Mataram. The training was attended by 22 participants from junior high school mathematics teachers in the city of Mataram. In the implementation of the training, an evaluation was carried out using questionnaires and observations. The conclusions from the results of the service were as follows: Geogebra training as a medium for learning mathematics for SMP teachers in the city of Mataram in 2021 received a very good response and was well received by the teachers. Geogebra training as a medium for learning mathematics for junior high school teachers in the city of Mataram in 2021 is very in line with what is expected by mathematics teachers in the City of Mataram and increases teacher competence in the context of applying technology in learning to develop technology-based mathematics learning media.
\end{abstract}

Keywords: Geogebra, Learning Media, Training

\begin{abstract}
Abstrak
Survey tahun 2019 diperoleh 82,2\% guru tidak pernah mengikuti pelatihan media terlebih lagi media pembelajaran berbasis teknologi geogebra. Sementara itu 92,8\% guru menyatakan bahwa matematika memerlukan media pembelajaran. Rendahnya mutu pendidikan di NTB memerlukan perhatian khusus baik dari pihak pemerintah maupun swasta sehingga penting untuk dilakukan pelatihan media pembelajaran berbasis teknologi dalam rangka meningkatkan mutu pendidikan khususnya meningkatkan mutu guru. Pelatihan dilaksanakan dengan metode offline dan online selama dua hari yaitu tanggal 19 dan 20 Agustus 2021 di SMPN 16 Mataram. Pelatihan dihadiri oleh 22 peserta guru matematika SMP sekota Mataram. Dalam pelaksanaan pelatihan dilakukan evaluasi dengan angket dan observasi diperoleh kesimpulan dari hasil pengabdian adalah sebagai berikut pelatihan geogebra sebagai media pembelajaran matematika pada Guru SMP di kota Mataram tahun 2021 mendapatkan respon sangat baik dan diterima dengan baik oleh guru-guru. Pelatihan Geogebra sebagai media pembelajaran matematika pada Guru SMP di kota Mataram tahun 2021 sangat sesuai dengan apa yang diharapkan oleh guru-guru matematika Sekota Mataram serta meningkatkan kompetensi guru dalam rangka penerapan teknologi dalam pembelajaran untuk mengembangkan media pembelajaran matematika berbasis teknologi.
\end{abstract}

Kata Kunci: Geogebra, Media Pembelajaran, Pelatihan 


\section{PENDAHULUAN}

Kualitas Pendidikan matematika tahun 2019 masih tergolong rendah. Pada tahun 2019 Indonesia belum dilanda pandemic covid-19 sebagaimana pada tahun 2020 dan tahun 2021 sehingga proses pembelajaran pun terganggu sehingga akan berdapak juga pada kulitas hasil. Rendahnya kualitas Pendidikan pada tahun 2019 dapat dilihat dari rendahnya hasil ujian nasional pada tahun 2019. Hasil ujian nasional secara nasional jenjang SMP menunjukkan bahwa matematika berada pada level terendah dibandingakan dengan mata pelajaran lainnya dengan nilai rata-rata 46,56. Pada tingkat provinsi matematika juga berada pada level terendah jika dibandingkan dengan mata pelajaran lainnya dengan rata-rata 38,76 . Jika dilihat pada tingkat kota Mataram maka dari 3051 siswa 2.507 siswa mendapat nilai rata-rata UN dibawah 55 (Kemdikbud, 2019).

Tabel 1. Data nilai UN SMP NTB 2019

\begin{tabular}{llll}
\hline No & Materi yang diuji & Provinsi & Nasional \\
\hline 1 & Bilangan & 33,46 & 41,44 \\
2 & Aljabar & 42,48 & 52,29 \\
3 & Geometri dan pengukuran & 38,13 & 43,52 \\
4 & Statistika dan peluang & 47,86 & 56,41 \\
\hline \multicolumn{2}{c}{ Sumber: Kemdikbud.go.id }
\end{tabular}

Berdasarkan Tabel 1 nilai UN mata pelajaran Matematika SMP di NTB berada di bawah 55 untuk setiap materi yang di uji terlebih lagi materi bilangan dan geometri dengan nilai rata-rata dibawah 40 . Nilai rata-rata UN mata pelajaran matematika SMP di NTB untuk semua materi berada di bawah nilai rata-rata nasional. Berdasarkan hal tersebut maka dapat dikatakan kemampuan siswa menerima materi kurang dari 40\%.

Beberapa faktor yang dapat mempengaruhi hasil belajar matematika siswa berdasarkan hasil penelitian diantaranya adalah minat belajar, sikap, kreativitas, kebiasaan belajar, disiplin, motivasi, lingkungan belajar, model pembelajaran, kompetensi guru, media pembelajaran. Hasil penelitian tentang minat belajar dan media pembelajaran menunjukkan bahwa hasil belajar siswa yang diajarkan dengan media pembelajaran 3 dimensi lebih tinggi daripada yang diajarkan dengan media 2 dimensi, lebih lanjut siswa dengan minat belajar yang tinggi memiliki hasil belajar yang lebih tinggi (Sugiati, 2016). Model pembelajaran yang digunakan berpengaruh terhadap motivasi belajar (Landong, 2019). Terdapat pengaruh langsung kompetensi professional guru dan motivasi belajar siswa terhadap hasil belajar siswa(Daryati, 2016). Kreativitas siswa berpengaruh terhadap hasil belajar matematika (Arifin, 2018). Kebiasaan belajar berpengaruh terhadap hasil belajar matematika(Nurdeni \& Liberna, 2012). Lingkungan belajar berpengaruh positif terhadap hasil belajar (Ningsih et al., 2019).

Berdasarkan undang-undang guru dan dosen, guru memiliki peran yang sangat penting terkait dengan mutu Pendidikan. Peran guru sebagai agen pembelajaran berfungsi untuk meningkatkan mutu pendidikan nasional. Guru harus memiliki komitmen untuk 
meningkatkan mutu pendidikan(Undang-undang RI, 2005). Guru harus meningkatkan kompetensi untuk dapat menjalankan peran sebagai agen pembelajaran. Salah satu kompetensi yang perlu ditingkatkan adalah kemampuan guru dalam menggunakan teknologi dalam pembelajaran.

Teknologi dalam pembelajaran menjadi sesuatu yang penting untuk dikuasai guru dikarenakan perkembangan teknologi yang sangat pesat. Setiap orang termasuk siswa tidak terlepas dari pengaruh teknologi. Tidak ada jalan lain untuk memanfaatkan teknologi selain dengan menerapkannya dalam pembelajaran. Penerapan teknologi dalam pembelajaran salah satunya adalah dengan menerapkanya dalam media pembelajaran. Dengan pemanfaat media, berbagai masalah yang abstrak diharapkan mampu divisualkan dengan baik oleh Guru. Salah satu media atau software untuk visualisasi matematika adalah media Geogebra. Namun sayang guru-guru khussnya di kota Mataram, belum banyak mengenal Geogebra apalagi menggunakannya. Oleh karena itulah pelatiahn dan pendampingan penggunaan media ini sangat diharapkan dapat dilakasanakn pada guru-guru tersebut.

Terdapat banyak penelitian yang menunjukkan bahwa media Geogebra penting untuk diterapkan dalam pembelajaran matematika. Pentingnya media geogebra dapat dilihat dari pengaruh media geogebra terhadap beberapa variabel yang berpengaruuh terhadap hasil belajar diantaranya adalah Pembelajaran matematika berbantuan Geogebra berpengaruh signifikan terhadap kemampuan spasial siswa jika dibandingkan dengan pembelajaran matematika tanpa bantuan Geogebra (Haris \& Rahman, 2018). Pembelajaran matematika dengan bantuan geogebra memiliki pengaruh positif terhadap kemampuan pemahaman matematika siswa (Purwanti et al., 2016). Hasil belajar siswa pada pembelajaran matematika dengan bantuan geogebra lebih tinggi dibandingkan dengan pembelajaran matematika tanpa bantuan media geogebra (Fitra \& Syahputra, 2018). Media geogebra berpengaruh terhadap Kemampuan pemecahan masalah matematika siswa (Nurfadilah \& Suhendar, 2018). Terdapat perbedaan signifikan motivasi dan kreativitas siswa dalam pembelajaran matematika dengan media geogebra dibandingkan dengan pembelajaran konvensional(Puspitawati et al., 2018)

Geogebra adalah perangkat lunak matematika dinamis untuk semua tingkatan Pendidikan yang terkait aritmatika, geometri, aljabar dan kalkulus. Geogebra memberikan refresentasi beberapa objek dalam grafik, aljabar, dan tebaran kerja yang saling berhubungan secara dinamis. Dengan geogebra memungkinkan untuk langsung terlibat dalam memanipulasi persamaan kurva dan koordinat. (Tung, 2018)

Survey tahun 2019 diperoleh hanya 17,8\% (5 orang dari 28 orang) guru pernah mengikuti pelatihan tentang media akan tetapi medianya bukan media berbasis teknologi seperti Geogebra dengan kata lain 82,2\% tidak pernah mengikuti pelatihan media. Hal ini berarti bahwa pelatihan tentang media pembelajaran matematika jarang di adakan. Sementara itu 92,8\% guru menyatakan bahwa matematika memerlukan 
media pembelajaran. Dengan menguasai Geogebra diharapkan guru-guru matematika dapat meningkatkan kualitas pembelaran dan meningkatkan mutu Pendidikan matematika dan kebutuhan akan media pembelajaran matematika berbasis teknologi akan terpenuhi. Keadaan darurat matematika yang ditandai rendahnya mutu Pendidikan matematika harus segera disikapi dengan Tindakan nyata yaitu dengan mengadakan pelatihan kepada guru matematika di Mataram NTB. Pelatihan yang akan dilakukan adalah dengan melatih guru-guru dalam menggunakan Geogebra sebagai media pembelajaran berbasis teknologi.

\section{METODE PELAKSANAAN}

Kegiatan pengabdian dilaksanakan selama dua hari yaitu tanggal 19 dan 20 Agustus 2021 di SMPN 16 Mataram. Peserta kegiatan adalah guru-guru matematika SMP sekota Mataram sebanyak 22 orang. Secara umum metode pelaksanaan kegiatan ini adalah sebagai berikut: Tahap persiapan, pelaksanaan dan tahap evaluasi. Berikut ini adalah desain pelaksanaan pengabdian:

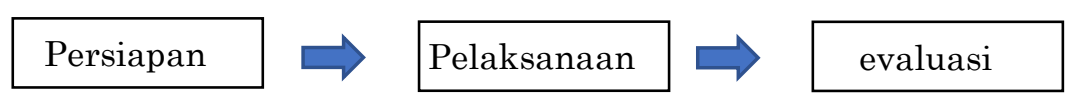

Langkah-langkah pelaksanaan sebagai berikut:

1. Pemaparan materi yang berkaitan dengan Media Pembelajaran Matematika.

2. Pelatihan penggunaan aplikasi geogebra .

3. Pelatihan pengembangan media pembelajaran berbasis geogebra.

4. Pengembangan media berbasis geogebra secara mandiri dan terstruktur.

5. Observasi proses dan kesulitan-kesulitan yang dialami guru dalam menerapkan geogebra sebagai media pembelajaran.

6. Evaluasi respon dengan pemberian angket kepada peserta.

\section{HASIL DAN PEMBAHASAN}

Program Pengabdian Kepada Masyarakat dilaksanakan dalam tiga tahapan yaitu tahap persiapan, tahap pelaksanaan dan tahap evaluasi.

a) Tahap Persiapan.

Pada tahap persiapan banyak hal yang dilakukan sebagai langkah persiapan pelaksanaan program pengabdian pada masyarakat. Tahap awal yang dilakukan adalah menentukan disposisi atau sebaran tugas dari masing-masing anggota. Adapun sebaran tugas tim adalah sebagai berikut: Dr.Amrullah ,S.Si, M.Si bertugas mengkoordinir setiap kegiatan mulai dari penyusunan proposal hingga pelaporan kegiatan pelatihan termasuk juga sebagai pemateri dalam kegiatan. Dr. Sudi Prayitno, M.Si bertugas menyusun kerangka materi yang akan disampaikan dalam kegiatan pelatihan serta memvalidasi materi yang telah disusun oleh tim pengabdian selain itu juga sebagai pemateri dalam pelatihan dan menyusun laporan bersama. Hapipi, S.Pd.,M.Si bertugas sebagai koordinator dalam rangka koordinasi dengan mitra hingga penjadwalan kegiatan serta sebagai pemateri dalam kegiatan pengabdian dan menyusun laporan bersama. Junaidi, S.Pd.,M.Pd dan Nilza Humaira Salsabila, 
S.Pd.,M.Pd bertugas melakukan koordinasi dan persiapan serta akomodasi kegiatan, menyusun materi, pemateri dan menyusun laporan kegiatan.

Dalam rangka pelaksanaan pengabdian, tim melakukan koordinasi dengan pihat Mitra yaitu SMPN 16 Mataram. Hasil koordinasi yang dilakukan adalah pelaksanaan program pengabdian yaitu Pelatihan Geogebra sebagai media pembelajaran matematika pada Guru SMP di kota Mataram tahun 2021 dapat dilaksanakan secara Offline dengan protokol kesehatan yang ketat. SMPN 16 Mataram sebagai tuan rumah penyelengaraan program dengan bertempat pada laboratorium Komputer sekolah.

Penyusunan proposal pengabdian dilaksanakan pada bulan Februari 2021 dengan melibatkan seluruh tim sesuai dengan disposisi tugas masing-masing. Proposal kemudian diajukan untuk mendapatkan pembiayaan kegiatan. Selanjutnya tim pengabdian menyusun modul dan materi yang akan disampaikan pada kegiatan pengabdian.

Setelah jadwal dan kuota peserta pelatihan ditetapkan pada tahap koordinasi maka dilakukan kegiatan diskusi yang berkaitan dengan agenda kegiatan serta mengundang peserta kegiatan. Hasil dari diskusi tersebut adalah sebagai berikut: 1. Pembagian materi yang akan disampaikan dan pemateri yang akan menyampaikan urutan dalam penyampaian materi pelatihan. 2. Penyusunan modul sederhana dalam rangka mempermudah peserta dalam memahami materi pelatihan. Modul pelatihan selengkapnya dapat dilihat pada Lampiran 1. 3. Disusun suatu instrument evaluasi dalam rangka mengetahui keterlaksanaan dan keefektifan kegiatan pelatihan. Tahap terakhir dalam persiapan adalah menyiapkan akomodasi, Spanduk dan sertifikat bagi para peserta kegiatan serta menyusun instrument evaluasi kegiatan

b) Tahap pelaksanaan.

Kegiatan pengabdian direncanakan akan dilakasanakan pada bulan Juli 2021 akhirnya dapat dilaksanakan pada bulan Agustus 2021. Berdasarkan hasil koordinasi tim pengabdian dengan SMPN 16 Mataram, kegiatan pelatihan dilaksanakan selama dua hari yaitu tanggal 19 dan 20 Agustus 2021. Kegiatan pelatihan dihadiri oleh 22 guru Matematika SMP sebagai peserta dari 25 peserta yang diundang. daftar peserta selengkapnya dapat dilihat pada Lampiran 2. Tanggal tersebut dipilih karena adanya edaran Gubernur tentang PPKM (Pemberlakuan Pembatasan Kegiatan Masyarakat) NOMOR :180/08/KUM/Tahun 2021 menyatakan bahwa Khusus Kota Mataram yang ditetapkan sesuai kriteria level situasi pandemi berdasarkan assesmen, dengan kriteria level 4 (empat) pada kondisi darurat pelaksanaan kegiatan belajar mengajar (Sekolah, Perguruan Tinggi, Akademi, Tempat Pendidikan/Pelatihan dilakukan secara daring/online; maka kegiatan pelatihan baru dapat dilaksanakan pada bulan Agustus 2021. Selain itu guru-guru Matematika memiliki agenda yang padat sebelum tanggal 19 Agustus 2021 karena bertepatan dengan acara peringatan hari kemerdekaan Indonesia. Kegiatan pelatihan seharusnya dihadiri oleh guru-guru matematika SMP sekota mataram, akan tetapi dengan adanya edaran Gubernur maka kuota peserta 
pelatihan dibatasi maksimal $50 \%$ dari daya tamping ruangan sehingga ditetapkan peserta sebanyak 25 orang buru matematika SMP sekota mataram.

Modul yang disusun bersama sebagai materi dalam kegiatan pengabdian memuat halhal sebagai berikut:

a. Latar belakang kegiatan

b. Mengenal geogebra

c. Menggunakan geogebra sebagai media pembelajaran

d. Mengembangkan media pembelajaran baru berbasis geogebra sesuai dengan kebutuhan guru

c) Tahap evaluasi.

Evaluasi kegiatan pengabdian dilaksanakan dengan dua metode yaitu menggunakan instrument evaluasi dan observasi langsung. Evaluasi dengan metode observasi langsung bertujuan untuk mengetahui kesulitan-kesulitan yang dihadapi peserta dalam menggunakan geogebra serta kesulitan yang dihadapi dalam mengembangkan media pembelajaran berbasis geogebra.

Evaluasi menggunakan instrument dilaksanakan dengan memberikan link survey yang berisikan angket yang berkaitan dengan bagaimana pelaksanaan pengabdian berupa Pelatihan Geogebra sebagai media pembelajaran matematika pada Guru SMP di kota Mataram tahun 2021. Angket berisikan 9 pertanyaan yang berkaitan dengan pelatihan dengan pertanyaan sebagai berikut:

a. Anda merasa puas dengan kegiatan pengabdian kepada masyarakat (PKM) yang dilaksanakan

b. Anda merasa puas dengan cara penyampaian narasumber

c. Materi yang disajikan pada kegiatan PKM sesuai dengan kebutuhan Anda

d. Materi yang disajikan dapat membantu Anda untuk melaksanakan pembelajaran matematika menjadi lebih baik

e. Kegiatan PKM yang dilaksanakan sesuai dengan harapan

f. Kegiatan PKM yang dilaksanakan memiliki kebermanfaatan

g. Kegiatan PKM yang dilaksanakan dapat dilanjutkan oleh mitra pengabdian

h. Jika kegiatan PKM diselenggarakan kembali, Anda tertarik untuk ikut serta

i. Silahkan tuliskan pendapat dan saran Bapak/Ibu secara singkat dan jelas terkait dengan kegiatan PKM yang dilaksanakan

Berdasarkan instrument evaluasi diperoleh bahwa:

a. $45 \%$ peserta menyatakan puas dan $55 \%$ menyatakan sangat puas dengan kegiatan pengabdian kepada masyarakat (PKM) yang dilaksanakan. 
b. $50 \%$ peserta menyatakan puas dan $50 \%$ menyatakan sangat puas dengan cara penyampaian narasumber

c. $55 \%$ peserta menyatakan puas dan $45 \%$ menyatakan sangat puas dengan Materi yang disajikan pada kegiatan PKM karena sesuai dengan kebutuhan Guru

d. $41 \%$ peserta menyatakan puas dan $59 \%$ menyatakan sangat puas dengan Materi yang disajikan dapat membantu guru untuk melaksanakan pembelajaran matematika menjadi lebih baik

e. $59 \%$ peserta menyatakan puas dan $41 \%$ menyatakan sangat puas dengan Kegiatan PKM yang dilaksanakan sesuai dengan harapan

f. $50 \%$ peserta menyatakan puas dan $50 \%$ menyatakan sangat puas dengan Kegiatan PKM yang dilaksanakan memiliki kebermanfaatan

g. $36 \%$ peserta menyatakan puas dan $64 \%$ menyatakan sangat puas dengan Kegiatan PKM yang dilaksanakan dapat dilanjutkan oleh mitra pengabdian

h. $32 \%$ peserta menyatakan puas dan $68 \%$ menyatakan sangat puas dengan Jika kegiatan PKM diselenggarakan kembali, guru tertarik untuk ikut serta

Pendapat dan saran Bapak/Ibu secara singkat dan jelas terkait dengan kegiatan PKM yang dilaksanakan: waktu pelaksanaan secara offline supaya ditambah karena konten materi geogebra masih banyak yang perlu untuk didalami, kegiatan Pengabdian supaya rutin diadakan sebagai penyegaran bagi guru-guru yang belum mahir dalam menggunakan teknologi khususnya menggunakan geogebra, berakhirnya kegiatan ini tidak hanya sampai disini tetapi terus secara berkesinambungan dengan membuat WA group untuk berdiskusi terkait dengan pengembangan media pembelajaran berbasis geogebra, diperlukan ada contoh pada setiap level atau kelas 7,8, dan 9 untuk media pembelajaran berbasis geogebra, pengabdian dilanjutkan dengan materi materi profesionalisme guru supaya dapat meningkatkan kompetensi guru.

Kegiatan dalam tahap persiapan mulai dari tahap penyusunan proposal hingga penjadwalan kegiatan tidak menemukan kendala-kendala yang berarti akan tetapi tetap memiliki beberapa kesulitan-kesulitan tertentu diantaranya adalah

a. Sulit menemukan irisan waktu yang tepat dimana seluruh anggota tim dapat hadir dalam kegiatan pengabdian serta sesuai dengan waktu luang yang ada disekolah mitra yaitu SMPN 16 Mataram. Kesulitan ini membuat tim menyimpulkan untuk membuat WA group untuk membahas irisan waktu yang tepat hingga semua tim dapat hadir. Setelah mendapatkan waktu yang tepat maka dilakukan koordinasi dengan pihak mitra. Dalam kegiatan koordinasi dengan pihak mitra ditemukan kendala bahwa di sekolah atau pihak mitra memiliki kegiatan pada waktu yang telah disepakati oleh tim yaitu pada 19 Juli 2021, sekolah dapat melaksanakan kegiatan pada bulan Agustus 2021 pada minggu ke 3-5 karena banyaknya kegiatan 
sekolah. Selanjutnya dilakukan diskusi kembali dengan tim melalui WA group kemudian ditetapkan minggu ketiga Agustus 2021 sebagai waktu pelaksanaan kegiatan pengabdian.

b. Kesulitan dalam metode pelaksanaan pelatihan. Kesulitan ini disebabkan karena Mataram dalam keadaan pandemic serta ditetapkan sebagai Zona merah sehingga tidak dapat melaksanakan kegiatan secara offline sehingga pada saat itu kegiatan pengabdian ditunda sampai status Zona merah berubah. Setelah status zona merah berubah dan aturan PPKM dilonggarkan maka kegiatan pengabdian dapat dilaksanakan dengan menerapkan protokol kesehatan yang ketat. kegiatan yang awalnya direncakan dua hari secara offline kemudian dirubah menjadi offline satu hari tanggal 19 Agustus 2021 dan online satu hari yaitu tanggal 20 Agustus 2021.

Kegiatan pengabdian dilaksanakan dengan dua metode yaitu metode offline dan Online. Pada pelaksanaan secara offline pelaksanaan kegiatan pengabdian dimulai pada pukul 10.00 WITA, setiap anggota tim mengambil bagian sebagai tutor dalam pelatihan. Kegiatan pelatihan berjalan dengan lancar yang dihadiri oleh 22 orang guru matematika sekota mataram. Guru-guru berasal dari beberapa sekolah di Mataram yaitu SMPN 16 Mataram, SMPN 4 Mataram, SMPN 23 Mataram, dan SMPN 2 Mataram. Pada awalnya jumlah sekolah yang diundang adalah sebanyak 12 sekolah akan tetapi banyak guru-guru yang tidak berani menghadiri kegiatan secara offline dikarena situasi kota mataram masih belum aman atau masih rawan dari penularan virus corona meskipun telah disampaikan bahwa kegiatan akan dilaksanakan dengan protokol kesehatan yang ketat.

Selain terkendala dengan banyaknya guru yang tidak berani menghadiri kegiatan beberapa kendala yang ditemukan dalam pelaksanaan adalah ketika ada guru dalam kegiatan pelatihan mengalami kesulitan tertentu dalam menggunakan aplikasi geogebra maka tim tidak leluasa untuk mendampingi karena harus menjaga jarak aman 1 meter dari peserta. Dengan segala keterbatasan yang ada guru-guru tetap antusias dalam mengikuti pelatihan tampak dari banyaknya pertnyaan-pertanyaan dari guru-guru yang mengalami kendala dalam menggunakan aplikasi geogebra. Pelaksanaan kegiatan secara online tidak dilakukan evaluasi karena merupakan kegiatan mandiri terstruktur bagi guru atau peserta dalam rangka melatih apa yang telah dipelajari dalam kegiatan secara offline.

Berdasarkan hasil evaluasi $55 \%$ peserta menyatakan puas dan $45 \%$ menyatakan sangat puas dengan Materi yang disajikan pada kegiatan PKM karena sesuai dengan kebutuhan Guru. Hal ini disebakan karena pada era 4.0 dengan pesatnya perkembangan teknologi maka salah satu cara untuk memanfaatkan teknologi adalah dengan menggunakannya sebagai media dalam pembelajaran matematika. Selain itu berdasarkan instrument akreditasi satuan pendidikan (IASP 2020) penerapan teknologi dalam pembelajaran merupakan suatu hal memiliki poin penting dalam penilaian proses pembelajaran sehingga akan memberikan kontribusi terhadap peningkatan mutu guru dalam meningkatkan kualitas pembelajaran disekolah. 
Berkaitan dengan cara penyampaian narasumber $50 \%$ peserta menyatakan puas dan $50 \%$ menyatakan sangat puas dengan cara penyampaian narasumber. Pelatihan dilakukan dengan membimbing langsung guru langkah demi langkah dalam menggunakan fitur-fitur geogebra. Sehingga ketika ada kendalan tententu dari guru maka langsung di bantu.

Berdasarkan observasi yang dilakukan oleh tim beberapa kesulitan yang dialami oleh guru dalam menggunakan geogebra adalah guru kesulitan dalam menggunakan formula-formula dalam geogebra atau rumus-rumus tertentu dalam geogebra hal ini karena guru belum terbiasa dan tidak mengetahui formula-formula dan cara-cara penggunaannya. Selain itu guru juga mengalami kesulitan dalam mengkombinasikan fitur-fitur geogebra untuk dirangkaikan menjadi suatu media pembelajaran. Hal ini berarti mengembangkan media berbasis geogebra membutuhkan kreativitas dari guru selain keterampilan menggunakan geogebra.

\section{SIMPULAN}

Berdasarkan hasil dan pembahasan maka diperoleh kesimpulan sebagai berikut: pelatihan geogebra sebagai media pembelajaran matematika pada Guru SMP di kota Mataram tahun 2021 mendapatkan respon sangat baik dan diterima dengan baik oleh guru-guru. Pelatihan Geogebra sebagai media pembelajaran matematika pada Guru SMP di kota Mataram tahun 2021 sangat sesuai dengan apa yang diharapkan oleh guru-guru matematika Sekota Mataram serta meningkatkan kompetensi guru dalam rangka penerapan teknologi dalam pembelajaran untuk mengembangkan media pembelajaran matematika berbasis teknologi

\section{UCAPAN TERIMA KASIH}

Ucapan terimakasih disampaikan pada LPPM Universitas Mataram yang telah mendanai pelaksanaan kegiatan pengabdian dan pihak SMPN 16 Mataram yang telah memberikan izin serta membantu menyediakan tempat pelaksanaan kegiatan. Selain itu, disampaikan terimakasih kepada pihak-pihak yang telah banyak membantu sehingga kegiatan pengabdian ini dapat berjalan dengan baik

\section{REKOMENDASI}

Pada pelaksanaan kegiatan pengabdian ini, kegiatan dilaksanakan secara terbatas jumlah peserta karena pemberlakukan PPKM, oleh karena itu jumlah peserta kurang refresentatif untuk mewakili seluruh guru matematika sekota Mataram sehingga perlu dilakukan pengabdian secara online bagi peserta guru yang tidak dapat hadir pada pengabdian. Selain itu diperlukan pembinaan lebih lanjut melalui WA group sebagai media diskusi dalam pengembangan media pembelajaran. 


\section{REFERENSI}

Arifin, S. (2018). Pengaruh Minat Dan Kreativitas Belajar Matematika Terhadap Hasil Belajar Matematika Siswa Kelas X Sma. HISTOGRAM: Jurnal Pendidikan Matematika, 2(1), 59. https://doi.org/10.31100/histogram.v2i1.121

Daryati, N. (2016). Pengaruh Kompetensi Profesional dan Motivasi Berprestasi Siswa Terhadap Hasil Belajar Matematika. Jurnal Penelitian Pendidikan Dan Penilaian Pendidikan, 1(1), 123-137. https://doi.org/10.22236/JPPP

Fitra, A., \& Syahputra, M. R. (2018). Pengaruh GeoGebra Terhadap Hasil Belajar Siswa Pada Materi SPLDV di Kelas VIII SMP Kemala Bhayangkari 1 Medan. Jurnal Mantik Penusa, 2(2), 92-97.

Haris, A., \& Rahman, A. (2018). Pengaruh Pembelajaran Berbasis Masalah (PBM) dengan Bantuan Geogebra Terhadap Kemampuan Spasial Mahasiswa. Jurnal Pendidikan MIPA, 8(1), 87-93.

Kemdikbud. (2019). Laporan Hasil Ujian Nasional. Kemdikbud.Go.Id. https://pusmenjar.kemdikbud.go.id/hasil-un/

Landong, A. (2019). Pengaruh Model Pembelajaran Quantum Berbasis Budaya Mandailing Natal Terhadap Motivasi dan Hasil Belajar Matematika Siswa. 01(02), 72-78.

Ningsih, S., Haryaka, U., \& J.R Watulingas. (2019). Pengaruh Motivasi, Lingkungan Belajar, dan Sikap Siswa terhadap Hasil Belajar Matematika Siswa. 8(1), 43-54.

Nurdeni, \& Liberna, H. (2012). Pengaruh Kebiasaan Belajar Dan Kreativitas Belajar Siswa Terhadap Hasil Belajar Matematika. Jurnal Fourier, 1(2), 71-76.

Nurfadilah, U., \& Suhendar, U. (2018). Pengaruh Penggunaan Geogebra Terhadap Kemampuan Pemecahan Masalah Siswa Pada Topik Garis Dan Sudut. JMPM: Jurnal Matematika Dan Pendidikan Matematika, 3(2), 99-107.

Purwanti, R. D., Pratiwi, D. D., \& Rinaldi, A. (2016). Pengaruh Pembelajaran Berbantuan GeoGebra Terhadap Pemahaman Konsep Matematis ditinjau dari Gaya Kognitif. AlJabar: Jurnal Pendidikan Matematika, $7(1), \quad 115-122$. https://doi.org/https://doi.org/10.24042/ajpm.v7i1.137

Puspitawati, N. M., Santayasa, I. W., \& Agustini, I. K. (2018). Pengaruh Media Geogebra Terhadap Motivasi Dan Kreativitas Belajar Matematika Siswa Smk Negeri 1 Singaraja. Jurnal Teknologi Pembelajaran Indonesia, 8(3). https://doi.org/10.23887/jtpi.v8i3.2286

Sugiati. (2016). Pengaruh Media Pembelajaran dan Minat Belajar Terhadap Hasil Belajar Matematika. Jurnal Penlitian Dan Penilaian Pendidikan, 1(2), 227-241. https://doi.org/10.30998/formatif.v2i1.86

Tung, K. Y. (2018). Mahir Geometri dan Matematika dengan Geogebra. Yogyakarta: ANDI.

Undang-undang RI. (2005). Undang-undang No.14 Tahun 2005 Tentang Guru dan Dosen. 